\title{
Relationship between overweight at 6 years of age and socioeconomic conditions at birth, breastfeeding, initial feeding practices and birth weight
}

Relação entre excesso de peso aos 6 anos de idade e condições socioeconômicas ao

nascimento, amamentação, práticas

iniciais de alimentação e peso ao nascer

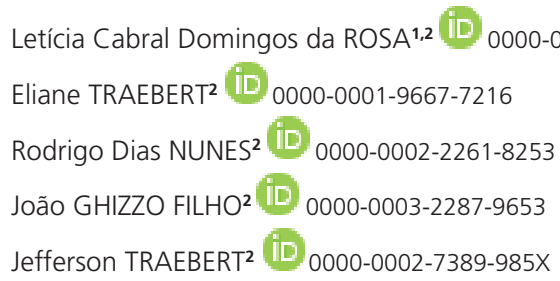

A B S T R A C T

\section{Objective}

To review the relationship between overweight at 6 years of age and socioeconomic conditions at birth, breastfeeding, early feeding practices and birth weight.

\footnotetext{
${ }^{1}$ Universidade Salvador, Curso de Enfermagem. Salvador, BA, Brasil.

2 Universidade do Sul de Santa Catarina, Curso de Medicina, Programa de Pós-Graduação em Ciências da Saúde. Av. Pedra Branca, 25, sala 119B, Cidade Universitária, 88132-270, Palhoça, SC, Brasil. Correspondence to: J TRAEBERT. E-mail: <jefferson.traebert@unisul.br>.

Support: Fundação de Amparo à Pesquisa e Inovação do Estado de Santa Catarina (Processo n. 2016TR222) e Programa de Suporte à Pós-Graduação de Instituições Comunitárias de Ensino Superior da Coordenação de Aperfeiçoamento de Pessoal de Nível Superior (Código de Financiamento 001).

Article elaborated from the dissertation by LCD ROSA, entitled "Incidência e efeito de práticas iniciais de alimentação e do peso ao nascer no sobrepeso/obesidade aos 6/7 anos de idade”. Universidade do Sul de Santa Catarina; 2017.
}

How to cite this article

Rosa LCD, Traebert E, Nunes RD, Ghizzo Filho J, Traebert J. Relationship between overweight at 6 years of age and socioeconomic conditions at birth, breastfeeding, initial feeding practices and birth weight. Rev Nutr. 2019;32e190033. http://dx.doi.org/10.1590/1678-9865201932e190033 


\section{Methods}

A cross-sectional study was carried out involving 473 six-year-old schoolchildren from public and private schools living in a municipality in Southern Brazil. Sociodemographic and breastfeeding data and other initial feeding practices were obtained through interviews with the mothers at home. Birth weight and gestational age were obtained from the child's health card. Anthropometric data of the schoolchildren were collected during school visits. Bivariate and multivariate analyzes were performed using the Poisson Regression between the independent variables and overweight.

\section{Results}

The prevalence of overweight was 33.2\%; $83.2 \%$ of the children were breastfed and out of these, $48.4 \%$ were breastfed only in the first six months. Non-breastfed children exhibited a $20 \%$ higher overweight prevalence $(P R=1.20 ; 95 \% \mathrm{Cl} 1.13 ; 1.28)$. Children with exclusive breastfeeding for six months exhibited a lower overweight prevalence $(\mathrm{PR}=0.94 ; 95 \% \mathrm{Cl} 0.89 ; 0.99)$.

\section{Conclusion}

In this study, breastfeeding showed to be a protective factor for overweight.

Keywords: Breast feeding. Birth weight. Child. Obesity. Overweight.

\section{R E S U M O}

\section{Objetivo}

Analisar a relação entre excesso de peso aos 6 anos de idade e condições socioeconômicas ao nascimento, amamentação, práticas iniciais de alimentação e peso ao nascer.

\section{Métodos}

Foi realizado um estudo transversal, envolvendo 473 escolares de 6 anos de idade de escolas públicas e privadas, residentes em um município do sul do Brasil. Dados sócio-demográficos e referentes à amamentação e outras práticas iniciais de alimentação foram obtidos por meio de entrevistas com as mães nos domicílios. O peso ao nascer e a idade gestacional foram obtidos por meio de consulta à carteira de saúde. Dados antropométricos dos escolares foram coletados em visitas às escolas. Foram realizadas análises bivariadas e multivariada por meio da Regressão de Poisson entre as variáveis independentes e o excesso de peso.

\section{Resultados}

A prevalência de excesso de peso foi de 33,2\%; 83,2\% das crianças foram amamentadas e desses, 48,4\% tiveram amamentação exclusiva nos primeiros seis meses. Crianças não amamentadas apresentaram prevalência $20 \%$ maior ( $R P=1,20$; IC95\% 1,13; 1,28) de excesso de peso. Crianças com amamentação exclusiva por seis meses apresentaram menor prevalência de excesso de peso ( $R P=0,94 ;$ IC95\% 0,89; 0,99).

\section{Conclusão}

O aleitamento materno neste estudo mostrou-se como um fator protetor para o excesso de peso.

Palavras-chave: Aleitamento materno. Peso ao nascer. Criança. Obesidade. Sobrepeso.

\section{INTROD U CTION}

The number of children reaching overweight levels is increasing globally. Although the prevalence of overweight in high-income countries is more than double that of middle- and lowincome countries, three-quarters of the world total overweight children live in economically poorer countries [1].

According to data from the Pesquisa de Orçamento Familiar (Family Budget Survey) carried out in Brazil in 2008 and 2009 [2], which is the latest large-scale survey in this country, overweight shows high prevalence rates, which have been increasing over the years. Interpretation of these data reveals that among children aged 5 to 9 years, $43.8 \%$ of the girls were above an ideal weight. Among boys of the same age group, the rates were even higher, $51.4 \%$. 
In Florianópolis, SC, Brazil, prevalence of overweight is similar to that shown in national data. In a survey that used the protocol proposed by the European Childhood Obesity Group involving a representative sample of 7 to 10 year olds who attended the first four years of elementary school, the prevalence of overweight was $22.1 \%$ [3]. In contrast, in another study conducted with third and fourth grade's students of public and private institutions also in Florianópolis, the overall prevalence of overweight was similar, 21.9\% [4]. More recently, in a study with schoolchildren aged 7 to 10 years, overweight rates were $36.2 \%$ in boys and $32.7 \%$ in girls [5]. Thus, the data show that the prevalence rates of overweight in childhood have never been as high as today in this locality.

Weight gain in childhood is a consequence of behavioral changes that have occurred in recent decades [1]. Such changes are due to social and environmental factors, including interpersonal (family, colleagues and social networks), community (school, workplace and institutions) and governmental (local, state and national policies) factors. These observations enhance the need for effective interventions and the implementation of programs for a fast reversal of these trends [1].

In a study on the health effects of overweight in Latin America [6], it was pointed out that identifying the determining factors is critical for developing well-informed health policies, actions, laws and regulations, i.e., measures based on scientific evidence. This is of great relevance because the high prevalence of overweight leads to an increase in associated morbidities such as diabetes, high blood pressure, dyslipidemia, hypercholesterolemia, cardiovascular diseases and development of the metabolic syndrome, which decreases quality of life and elevates the cost of health care $[6,7]$ Ward et al. [8] developing a simulation model to estimate the risk of obesity at age 35 for the United States (US) child population found that those individuals severely obese at 2 years of age have only one chance in 5 of not being obese at 35 years of age. They also estimated that at 5 years this chance is halved and concluded that persistent obesity dramatically increases the risk of overweight in adulthood.

In 2014 the Pan American Health Organization presented an action plan for obesity prevention proposing the implementation of a series of actions that include the promotion of breastfeeding and healthy eating. In addition, they proposed improvement of nutrition environments and school physical activity; fiscal policies and regulation of food marketing and labeling; ongoing surveillance, investigation and evaluation, as well as other multisectoral actions [9].

Many studies show that the duration of breastfeeding, exclusive breastfeeding until 6 months of age and the period of introduction of cow's milk and dairy products are associated with children's excess weight $[1,10-14]$ pointing to the hypothesis of breast milk having a protection effect against excessive weight gain. Victora et al. [15] presented the beneficial effects of long-term breastfeeding through a meta-analysis. They concluded about the protective effect against overweight, infections, malocclusions and improvement in intelligence indicators and diabetes.

Possible biological explanations for breastfeeding being protective for overweight include better development of self-regulation of food intake, the participation of breast milk in metabolic programming, changing fat cells both morphologically and in number or even inducing the phenomenon of metabolic differentiation $[15,16]$, among others.

Since overweight has a complex etiology and lasts a long time, it is important to study the influence of early life in the individuals' health-disease process. Thus, the objective of this study is to review possible associations between socioeconomic conditions at birth, breastfeeding, initial feeding practices and birth weight and overweight in 6-year-old schoolchildren. 


\section{METHODS}

This is a cross-sectional study nested in a cohort called Coorte Brasil Sul (Brazil South Cohort) [17] involving schoolchildren born in 2009 and their families enrolled in public and private schools in the Municipality of Palhoça, SC. The children were enrolled in their large majority in the first year of elementary school. Palhoça is located in the Greater Florianópolis metropolitan region, with an estimated 164,927 inhabitants in 2017. The Human Development Index (HDI) is 0.757, (43 ${ }^{\text {rd }}$ municipality in the Santa Catarina State and $420^{\text {th }}$ in the country) [18].

The total population of children born in 2009 resident in Palhoça and enrolled in the municipality's schools was 1,670 [17]. The minimum sample number with $80 \%$ power to detect a difference in the prevalence of overweight in children who were $20 \%$ exposed to an independent variable studied (in this case, non-breastfed children) and among 10\% unexposed, which generates a Prevalence Ratio of 2.0 at a significance level of $95 \%$, totaled 398 schoolchildren. Assuming $20 \%$ potential losses and refusals, the total sample was accrued accordingly and set at 477 students. The sample size was calculated using the OpenEpi program. The sample units were randomly selected from the database of the Coorte Brasil Sul [17], guaranteeing the conditions of concurrent existence of data from two investigation instruments: questionnaire and anthropometric form. The inclusion criteria in the cohort were children born in the year 2009, coming from families living in Palhoça, SC and enrolled in the Municipality schools. Children whose mothers or guardians were not found at home in three visits, including one on the weekend, were considered lost.

The dependent variable of the study was overweight (Body Mass Index [BMI] z-score >+1). The independent variables were: gender; ethnicity/skin color reported by mother (categorized as white and non-white); father's and mother's occupation at birth (categorized as being with and without income); father and mother's education at birth (categorized as 0 to 8 years of study completed or more than 8 years); birth weight in relation to gestational age (appropriate for gestational age: 10 90 percentile; large for gestational age: $>90$ percentile); breastfeeding (if the child was breastfed during the first 2 years of life: yes and no); exclusive breastfeeding for 6 months (yes and no); period of introduction of milk and dairy products (categorized as before 6 months and after 6 months); use of flours to supplement a baby bottle up to 2 years of age (yes and no); use of sugar, honey or molasses in the bottle until 2 years of age (yes and no) and use of fruits before sixth month of life (yes and no).

Data collection was performed through interviews (ethnicity/skin color reported by the mother, father's and mother's occupation at birth; father's and mother's education at birth; breastfeeding; time duration of exclusive breastfeeding; period of introduction of milk and dairy products; use of flours to supplement a feeding bottle up to 2 years of age; use of sugar, honey or molasses in the bottle up to 2 years of age and use of fresh or processed fruits), document data (birth weight; gestational age) and anthropometric measurements (children's weight and height). The interview was conducted with the mother or, in her absence, with the child's main caregiver, at home, by teams composed of nurses, nutritionists and community health agents, all trained in a 30-hour activity program. Document data were obtained from the child's health card at the time of the interview. The anthropometric evaluation was performed in the schools. An interview script and an anthropometric evaluation form were specially designed for this study.

The anthropometric evaluation of the students was performed based on the BMI, obtained by calculating the weight over squared height according to the World Health Organization Standards. 
Children's weight and height were collected in schools by the method recommended by the Brazilian Ministry of Health for this purpose $[19,20]$. The collection team consisted of nurses and nutritionists properly trained for this purpose.

Anthropometric data were collected in duplicate in $5 \%$ of the study population, selected at random, in order to allow monitoring of diagnostic reproducibility. A lack of the parents' signature of the Free and Informed Consent Form or of the children's consent was considered a loss. A pilot study was carried out with students not included in the study, with about $5 \%$ of all children aiming to test the proposed methodology, which proved to be feasible.

The anthropometric data obtained were entered into Excel spreadsheets and later imported by the Anthroplus Program (Geneze, Switverland, 2009) [21] where the nutritional diagnosis classifications of the population involved were performed. Birth weight and gestational age were entered into Excel spreadsheets and later imported by the Intergrowth-2 $1^{\text {st }}$ Program [22] where children were classified as appropriate or big for their gestational age.

Subsequently, all data were imported by the IBM ${ }^{\circledR}$ SPSS ${ }^{\circledR}$ 18.0 Statistics Program (New York, United States), where they were reviewed. Bivariate analyzes were performed to test proportions homogeneity by means of chi-square, with significance level lower than or equal to 0.05 . Multivariate analysis was performed using Poisson Regression with robust estimator to estimate the effects of any confounding variables, estimating the Prevalence Ratios (PR) and their relevant confidence intervals. Therefore, variables with $p<0.25$ in the bivariate analysis were included in a model using the stepwise backward method so that all significant variables had their effect adjusted. In the final model variables with significance level lower than or equal to 0.05 were maintained.

This study was approved by the Research Ethics Committee of the Universidade do Sul de Santa Catarina according to the CAAE opinion 38240114.0.0000.5369.

\section{RESULTS}

A total of 473 6-year-old schoolchildren and their families participated in the study, providing a response rate of $99.1 \%$. However, this number was different between the variables, since in some of them the information was unknown or was unavailable.

Most participants were male (53.1\%), Caucasian (83.2\%). These and other data on parent's education and occupation at birth can be found in Table 1. The prevalence of thinness was $1.7 \%$, eutrophy $64.9 \%$, overweight $21.2 \%$ and obesity $12.0 \%$. The prevalence of overweight (sum of overweight and obesity percentages) was $33.2 \%(95 \% \mathrm{Cl} 28.9 ; 37.5)$. No socio-demographic variable was associated with overweight (Table 1). Regarding breastfeeding, the results showed that $91.1 \%$ of children were breastfed at some point in time in their lives. Out of these, $48.4 \%$ were under exclusive breastfeeding in the first 6 months of their life. Regarding other feeding practices, $14.2 \%$ of the sample had milk and dairy products introduced before 6 months of age. Overweight was associated with non-breastfeeding $(p=0.006)$; in children who were not exclusively breastfed for six months, the prevalence of overweight was higher $(p=0.031$ ) (Table 2$)$. However, the smaller number of respondents in the variable "exclusive breastfeeding for 6 months" ( $n=353$ ) should be pointed out. This was due to the failure to remember in many cases whether breastfeeding had in fact been exclusive until the sixth month, although the respondents knew whether or not they had breastfed their offspring $(n=470)$. 
The results of the multivariate analysis are presented in Table 3. Non-breastfed children had a $20 \%$ higher overweight prevalence ( $P R=1.20 ; 95 \% \mathrm{Cl} 1.13 ; 1.28)(p<0.001)$, compared to those children who had been breastfed independently of the other variables studied. In addition, children exclusively breastfed for six months exhibited a lower overweight prevalence ( $P R=0.94 ; 95 \% \mathrm{Cl} 0.89$; $0.99)(p<0.037)$ also independently of the other variables studied.

Table 1. Sociodemographic characteristics of the studied sample. Palhoça (SC), 2015

\begin{tabular}{|c|c|c|c|c|c|c|c|}
\hline \multirow{3}{*}{ Variables } & \multicolumn{7}{|c|}{ Overweight } \\
\hline & \multicolumn{2}{|c|}{ Yes } & \multicolumn{2}{|c|}{ No } & \multicolumn{2}{|c|}{ Total } & \multirow{2}{*}{$p$} \\
\hline & $\mathrm{n}$ & $\%$ & $n$ & $\%$ & $\mathrm{n}$ & $\%$ & \\
\hline Gender $(n=473)$ & & & & & & & 0.162 \\
\hline Male & 91 & 31.5 & 160 & 63.7 & 251 & 53.1 & \\
\hline Female & 67 & 30.2 & 155 & 69.8 & 222 & 46.9 & \\
\hline Ethnicity/Skin Color $(n=473)$ & & & & & & & 0.674 \\
\hline Caucasian & 130 & 33.0 & 264 & 67.0 & 394 & 83.2 & \\
\hline Other & 28 & 35.4 & 51 & 64.6 & 79 & 16.8 & \\
\hline Father's Occupation at Birth $(n=445)$ & & & & & & & 0.605 \\
\hline With income & 141 & 33.0 & 286 & 67.0 & 427 & 92.0 & \\
\hline Without income & 7 & 38.9 & 11 & 61.1 & 18 & 8.0 & \\
\hline Mother's Occupation at Birth $(n=464)$ & & & & & & & 0.237 \\
\hline With income & 82 & 36.3 & 144 & 63.7 & 226 & 48.7 & \\
\hline Without income & 74 & 31.1 & 164 & 68.9 & 238 & 51.3 & \\
\hline Father's Education at Birth $(n=371)$ & & & & & & & 0.567 \\
\hline 0 to 8 years completed & 73 & 33.8 & 143 & 66.2 & 216 & 58.2 & \\
\hline Over 8 years completed & 48 & 31.0 & 107 & 69.0 & 155 & 41.8 & \\
\hline Mother's Education at Birth $(n=436)$ & & & & & & & 0.687 \\
\hline 0 to 8 years completed & 67 & 32.5 & 139 & 67.5 & 206 & 47.2 & \\
\hline Over 8 years completed & 79 & 34.3 & 151 & 65.7 & 230 & 52.8 & \\
\hline
\end{tabular}

\section{DISCUSSION}

The present study found a prevalence of overweight at 6 years of age associated with breastfeeding, but not with family socioeconomic conditions at birth, birth weight and some initial feeding practices. At 6 years of age non-breastfed children exhibited a higher overweight prevalence and those with exclusive breastfeeding for 6 months had a lower overweight prevalence.

Many international studies indicate a growing childhood obesity $[1,6,23,24]$. In Brazil, it is not different. In this investigation, the rate of overweight and obesity was quite high (33.2\%) comparable to another study conducted also in the Greater Florianópolis metropolitan region where the rate found was $34.5 \%$ among schoolchildren aged 7 to 10 years [5].

In the present study, there was no statistically significant association between overweight, gender and ethnicity of the schoolchildren. Ogden et al. [25] investigating obesity prevalence trends in US children and adolescents, found a significant increase of obesity prevalence in boys, but not in girls. As for ethnicity, in another North American study, the prevalence of obesity was higher among Hispanic children compared to non-Hispanic white children of all ages [26]. 
Table 2. Birth weight, breastfeeding and feeding characteristics of the studied sample. Palhoça (SC), 2015.

\begin{tabular}{|c|c|c|c|c|c|c|c|}
\hline \multirow{3}{*}{ Variables } & \multicolumn{7}{|c|}{ Overweight } \\
\hline & \multicolumn{2}{|c|}{ Yes } & \multicolumn{2}{|c|}{ No } & \multicolumn{2}{|c|}{ Total } & \multirow{2}{*}{$p$} \\
\hline & $\mathrm{n}$ & $\%$ & $\mathrm{n}$ & $\%$ & $\mathrm{n}$ & $\%$ & \\
\hline Birth weight in connection with Gestational Age $(n=378)$ & & & & & & & 0.981 \\
\hline Adequate to the Gestational Age ( $\geq$ Percentile 10-90) & 107 & 34.6 & 202 & 65.4 & 309 & 81.7 & \\
\hline Big for Gestational Age (>Percentile 90) & 24 & 34.8 & 45 & 65.2 & 69 & 18.3 & \\
\hline Breastfeeding $(n=470)$ & & & & & & & 0.006 \\
\hline Yes & 135 & 31.5 & 293 & 68.5 & 428 & 91.1 & \\
\hline No & 22 & 52.4 & 20 & 47.6 & 42 & 8.9 & \\
\hline Exclusive breastfeeding during 6 months $(n=353)$ & & & & & & & 0.031 \\
\hline Yes & 43 & 25.1 & 128 & 74.9 & 171 & 48.4 & \\
\hline No & 65 & 35.7 & 117 & 64.3 & 182 & 51.6 & \\
\hline Milk and dairy products period of introduction $(n=464)$ & & & & & & & 0.538 \\
\hline Before 6 months & 20 & 30.3 & 46 & 69.7 & 66 & 14.2 & \\
\hline After 6 months & 136 & 34.2 & 262 & 65.8 & 398 & 85.8 & \\
\hline Flour use added to Baby Bottle up to 2 Years $(n=461)$ & & & & & & & 0.500 \\
\hline Yes & 93 & 31.8 & 199 & 68.2 & 292 & 63.3 & \\
\hline No & 59 & 34.9 & 110 & 65.1 & 169 & 36.7 & \\
\hline Use of sugar, honey or molasses in the bottle until 2 years $(n=466)$ & & & & & & & 0.741 \\
\hline Yes & 44 & 32.4 & 92 & 67.6 & 136 & 29.2 & \\
\hline No & 112 & 33.9 & 218 & 66.1 & 330 & 70.8 & \\
\hline Fruits use before 6 months ( $n=465$ ) & & & & & & & 0.081 \\
\hline Yes & 52 & 39.4 & 80 & 60.6 & 132 & 28.4 & \\
\hline No & 103 & 30.9 & 230 & 69.1 & 333 & 71.6 & \\
\hline
\end{tabular}

Table 3. Association between overweight and sociodemographic variables, breastfeeding and fruit consumption. Palhoça (SC), 2015.

\begin{tabular}{|c|c|c|c|c|c|c|}
\hline \multirow{2}{*}{ Variables } & \multicolumn{6}{|c|}{ Overweight } \\
\hline & $\mathrm{PR}_{\mathrm{c}}$ & $95 \% \mathrm{Cl}$ & $p$ & $\mathrm{PR}_{\mathrm{a}}$ & $95 \% \mathrm{Cl}$ & $p$ \\
\hline Gender & & & 0.162 & $\#$ & & \\
\hline Male & 1.00 & & & & & \\
\hline Female & 0.96 & $0.91 ; 1.01$ & & & & \\
\hline Mother's Occupation at Birth & & & 0.237 & $\#$ & & \\
\hline With income & 1.00 & & & & & \\
\hline Without income & 0.97 & $0.92 ; 1.02$ & & & & \\
\hline Breastfeeding & & & 0.006 & & & $<0.001$ \\
\hline Yes & 1.00 & & & 1.00 & & \\
\hline No & 1.14 & $1.03 ; 1.27$ & & 1.20 & $1.13 ; 1.28$ & \\
\hline Exclusive breastfeeding up to 6 months & & & 0.031 & & & 0.037 \\
\hline Yes & 1.00 & & & 1.00 & & \\
\hline No & 0.94 & $0.89 ; 0.99$ & & 0.94 & $0.89 ; 0.99$ & \\
\hline Fruits use before 6 months & & & 0.081 & * & & \\
\hline Yes & 1.00 & & & & & \\
\hline No & 0.95 & $0.89 ; 1.01$ & & & & \\
\hline
\end{tabular}

"Not included in the model because it presents collinearity with the variable "Exclusive breastfeeding up to the sixth month" (p<0,001); \#: No Statistical Significance; PRg: Crude Prevalence Ratio; PRa: Adjusted Prevalence Ratio. 
The significant association between overweight and socioeconomic conditions is shown in many papers $[1,6,26]$. However, the non-association found here corroborates the findings of another study performed in the same region where no statistical association was found between family income and overweight in children [5]. Rivera et al. [6] claim that prevalence of overweight at 5 years of age is higher in Latin America than elsewhere in the world, due to existing socioeconomic differences and low purchasing power of the population, leading to a higher consumption of affordable food, but mostly hypercaloric. The authors conclude that diets called obesogenic, because they are based on foods rich in sugar and dense energy, but poor in nutrients, are often the only foods within reach of this portion of the population.

Still in the same line of reasoning, parents' education at birth was not associated with the prevalence of overweight at 6 years. These results differ from a European study in which the prevalence of obesity was twice as high in Danish children and adolescents with low-educated parents as compared to parents with higher education. The authors add that those data are consistent with many other studies in that country that relate children overweight to this aspect [27].

Also, the present study found no statistically significant association between birth weight and overweight at 6 years. However, Goergen et al. [28] when reviewing the relationship between birth weight and time of breastfeeding with the nutritional status of children aged 2 to 6 years, obtained different results. They pointed out that birth weight was positively associated with current weight. They also found that in children born weighing more than 4,000g the probability of becoming overweight was higher.

In the present investigation, a statistically significant association was observed between breastfeeding and overweight. Non-breastfed children had a $20 \%$ higher prevalence of being overweight at 6 years of age compared to those who were breastfed. In addition, children who had been exclusively breastfed for 6 months had a lower prevalence of overweight at 6 years of age compared to those who were not breastfed for the same period. Offering other foods before 6 months, besides being unnecessary, can be harmful because it increases the risk of the child becoming ill, and may impair the absorption of important nutrients available in breast milk, such as iron and zinc [13]. Weaning should occur naturally and begin only after 2 years of age [15,29-31].

The Brazilian Ministry of Health [32] in the latest review of its Child Health-related Cadernos de Atenção Básica (Primary Care Notes) reiterates that breastfeeding reduces the chance of obesity. In a systematic review assessed by the Ministry of Health on evidence of long-term effect of breastfeeding, breastfed individuals were $22 \%$ less likely to become overweight $[32,33]$. Thus, it is possible that there is a dose/response relationship with the period of breastfeeding, i.e., the longer the individual was breastfed, the lower the chance of becoming overweight. Possible mechanisms involved in this protection include better development of self-regulation of food intake in breastfed children; the unique composition of breast milk that participates in the metabolic programming process, for example changing the number and/or size of fat cells or inducing the phenomenon of metabolic differentiation. Moreover, it has been found that cow's milk may alter the metabolic rate during sleep of breastfed children, which may be associated with metabolic programming and the development of overweight $[15,34]$. Further, associating the protective effect of breastfeeding to overweight, the WHO, based on a systematic review published in 2013, emphasizes that protein intake as well as energy metabolism are lower among breastfed individuals [34]. Still, Scholtens et al. [35] suggest that 
differences in dietary preferences could be related to such an association. The authors report that at 7 years of age, Dutch children who were breastfed for more than 16 weeks exhibited a higher intake of fruits and vegetables compared to those who had never been breastfed. Those children were also less likely to consume white bread, soda, chocolate, and fried snacks [35].

On the other hand, in the present study, when the nutritional status at 6 years of age was referred to the period of introduction of other milks and dairy products, the use of flours as feed bottle complements and the use of sugar, honey or molasses in the bottle until 2 years of age no significant differences between no overweight and overweight groups were observed. However, studies have shown evidence that these factors are associated with a higher prevalence of obesity and a higher BMI in children [29,36-38]. The Ministry of Health [31] pointed out that among formulafed infants, the introduction of solid food before four months of age was associated with a six-fold increase in the chance of obesity at 3 years of age.

In the first 2 years of the child's life, the choice of food deserves special attention, because that is the time when eating habits are being formed. Studies $[30,32,34]$ show that sweeteners, sugar, and products with these ingredients should not be offered to children. Eating sweets increases the chance of excessive weight gain and other diseases such as tooth decay, diabetes, hypertension, and cancer. Honey, despite being a natural product, is not recommended for children under 2 years of age as it contains many components of sugar and increases the risk of bacterial contamination associated with botulism in children under one year of age [31,33].

Limitations of this study include the fact that the questionnaire used required answers in connection with what happened in the past in the children's and family's life, which may have generated a potential memory bias. However, many investigations have shown that the technique can be used because it presents acceptable levels of information validity and is used in populationbased surveys conducted in Brazil [2]. Still regarding the questionnaire, one could think about very broad questions used about the age of infant feeding, since there are specific recommendations for the first year of life. However, the use of this questionnaire is justified by the fact that the present work is nested in a larger study [17] with other broader objectives. Even so, caution is recommended in interpreting the results given here, since comparing breastfed children during different time durations may also lead to potentially different effects on the outcome assessed.

Based on the results of the present study, further investigations are recommended to better understand the determinants of childhood overweight. In addition, knowing the difficulty in treating overweight in adulthood, especially due to its association with other chronic diseases, health promotion and prevention starting in childhood seem to be the most effective means of reducing the incidence and prevalence of overweight. Moreover, awareness of the epidemiological situation is of fundamental importance to yield proper inferences about overweight among schoolchildren of the age group studied, which can support the planning of appropriate interventions at local level for such important public health issue.

\section{CONCLUSION}

Breastfeeding in this study proved to be a protective factor for overweight at 6 years of age. Socioeconomic conditions, other initial feeding practices, and birth weight were not associated with overweight. 


\section{CONTRIBUTORS}

LCD ROSA, contributed to study conception and design, data collections, data analysis and interpretation, review and approval of the final version. E TRAEBERT, RD NUNES and J GHIZZO FILHO, contributed to data analysis and interpretation, review and approval of the final version. J TRAEBERT, contributed to study conception and design, data analysis and interpretation, review and approval of the final version.

\section{REFERENCES}

1. Black RB, Victora CG, Walker SP, Bhutta ZA, Christian P, Onis M, et al. Maternal and child nutrition 1: Maternal and child under nutrition and overweight in low-income and middle-income countries. Lancet. 2013;382:427-51.

2. Instituto Brasileiro de Geografia e Estatística. Pesquisa de Orçamentos Familiares 2008-2009. Brasília: IBGE; 2009 [citado 9 abr. 2019]. Disponível em: http:www.ibge.gov.br/home/presidencia/noticias/.../0000000108. pdf.

3. Assis MAA, Rolland-Cachera MF, Grosseman S, Vasconcelos FAG, Luna MEP, Calvo MCM, et al. Obesity, overweight and thinness in schoolchildren of the city of Florianópolis, Southern Brazil. Eur J Clin Nutr. 2005;59(9):1015-21.

4. Gabriel CG, Santos MV, Vasconcelos FAG. Avaliação de um programa para promoção de hábitos alimentares saudáveis em escolares de Florianópolis, Santa Catarina, Brasil. Rev Bras Saúde Matern Infant. 2008;8(3):299308.

5. Bernardo CO, Pudla KJ, Longo GZ, Vasconcelos FAG. Fatores associados ao estado nutricional de escolares de 7 a 10 anos. Rev Bras Epidemiol. 2012;15(3):651-61.

6. Rivera JA, Cossío TG, Pedraza LS, Aburto TC, Sánchez TG, Martorell R. Childhood and adolescent overweight and obesity in Latin America: A systematic review. Lancet Diabetes Endocrinol. 2014;2:321-32.

7. Afshin A, Forouzanfar MH, Reitsma MB, Patrick S, Estep K, Lee A, et al. Health effects of overweight and obesity in 195 countries. N Engl J Med. 2017;377:13-27.

8. Ward ZJ, Long MW, Resch SC, Giles CM, Cradock AL, Gortmaker SL. Simulation of growth trajectories of childhood obesity into adulthood. N Engl J Med. 2017;377:2145-53.

9. Organização Mundial de Saúde. Organização Pan-Americana da Saúde. Plano de ação para a prevenção de obesidade em crianças e adolescentes. Washington (DC): OMS; 2014.

10. Goergen IB, Bosco SMD, Adami FS. Relação entre o peso ao nascer e o tempo de aleitamento materno com o estado nutricional atual de crianças. Rev Bras Promo Saúde. 2015;28(3):344-50.

11. Zarrati M, Shidfar F, Moradof M, Nejad FN, Keyvani H, Hemami MR, et al. Relationship between breast feeding and obesity in children with low birth weight. Iran Red Crescent Med J. 2013;15(8):676-82.

12. Leary SD, Lawlor DA, Smith GD, Brion MJ, Ness AR. Behavioural early-life exposures and body composition at age 15 years. Nutr Diabetes. 2015;5(2):150-7.

13. Wang J, Wu Y, Xiong G, Chao T, Jin Q, Liu R, et al. Introduction of complementary feeding before 4 months of age increases the risk of childhood overweight or obesity: A meta-analysis of prospective cohort studies. Nutr Res. 2016;36:759-70.

14. Fewtrell M, Bronsky J, Campoy C, Domellöf M, Embleton N, Mis NF, et al. Complementary feeding: A position paper by the European Society for Paediatric Gastroenterology, Hepatology, and Nutrition (ESPGHAN) Committee on Nutrition. J Pediatr Gastroenterol Nutr. 2017;64:119-32.

15. Victora CG, Bahl R, Barros AJD, França GVA, Horton S, Krasevec J, et al. Breastfeeding in the $21^{\text {st }}$ century: epidemiology, mechanisms, and lifelong effect. Lancet. 2016;387:475-90.

16. Haisma H, Wells JC, Coward WA, Filho DD, Victora CG, Vonk RJ, et al. Complementary feeding with cow's milk alters sleeping metabolic rate in breast-fed infants. J Nutr. 2005;135(8):1889-95.

17. Traebert J, Lunardelli SE, Martins LGT, Santos K, Nunes RD, Lunardelli AN, et al. Methodological description and preliminary results of a cohort study on the influence of the first 1,000 days of life on the children's future health. An Acad Bras Cienc. 2018;90(3):3105-14. 
18. Programa das Nações Unidas para o Desenvolvimento (Brasil). Athas do desenvolvimento humano no Brasil. Brasília: PNDU; 2013 [citado 10 out. 2018]. Disponível em: http://www.pnud.org.br/IDH/Atlas2013. aspx? indiceAccordion=1\&li=li_Atlas2013

19. Ministério da Saúde (Brasil). Secretaria de Atenção à Saúde. Incorporação das curvas de crescimento da Organização Mundial de Saúde de 2006 e 2007 no SISVAN. Brasília: Ministério da Saúde; 2008 [citado 10 nov. 2018]. Disponível em: http://www.nutricao.saude.gov.br/docs/geral/curvas_oms_2006_2007.pdf

20. Ministério da Saúde (Brasil). Secretaria de Atenção à Saúde. Orientações para a coleta e análise de dados antropométricos em serviços de saúde: norma técnica do Sistema de Vigilância Alimentar e Nutricional SISVAN. Brasília: Ministério da Saúde; 2011.

21. World Health Organization. AnthroPlus for personal computers manual. Geneva: WHO; 2019 [cited 2018 Aug. 15]. Available from: http://www.who.int/growthref/tools/who_anthroplus_manual.pdf

22. Intergrowth-21 $1^{\text {st }}$. Manual entry. Oxford (UK): Orford University; 2019 [cited 2018 Sept. 02]. Available from: http://www.intergrowth21.ndog.ox.ac.uk/en/ManualEntry.

23. Ogden CL, Carroll MD, Kit BK, Flegal KM. Prevalence of childhood and adult obesity in the United States, 2011-2012. Jama. 2014;311(8):806-14.

24. Skinner AC, Perrin EM, Moss LA, Skelton JA. Cardiometabolic risks and obesity severity in children. N Engl J Med. 2015;373:1307-17.

25. Ogden CL, Carroll MD, Kit BK, Flegal KM. Prevalence of obesity and trends in body mass index among US children and adolescents, 1999-2010. Jama. 2012;307:483-90.

26. Cunningham SA, Kramer MR. Narayan KMV. Incidence of childhood obesity in the United States. N Engl J Med. 2014;370:403-11.

27. Matthiessen J, Stockmarr A, Biltoft-Jensen A, Fagt S, Zhang H, Groth MV. Trends in overweight and obesity in Danish children and adolescents: 2000-2008 - Exploring changes according to parental education. Scand J Public Health. 2014;42385-92.

28. Goergen IB, Bosco SMD, Adami FS. Relação entre o peso ao nascer e o tempo de aleitamento materno com o estado nutricional atual de crianças. Rev Bras Promo Saúde. 2015;28(3):344-50.

29. Pluymen LPM, Wijga AH, Gehring U, Koppelman GH, Smit HA, Van Rossem L. Early introduction of complementary foods and childhood overweight in breastfed and formula-fed infants in the Netherlands: The PIAMA birth cohort study. Eur J Nutr. 2018;57(5):1985-93.

30. Huh SY, Rifas-Shiman SL, Taveras EM, Oken E, Gillman MW. Timing of solid food introduction and risk of obesity in preschool-aged children. Pediatrics. 2011;127(3):544-51.

31. Ministério da Saúde (Brasil). Coordenação Geral de Alimentação e Nutrição. Guia alimentar para crianças menores de 2 anos: versão para consulta pública. Brasília: Ministério da Saúde; 2018.

32. Ministério da Saúde (Brasil). Secretaria de Atenção à Saúde. Saúde da criança: aleitamento materno e alimentação complementar. 2ed. Brasília: Ministério da Saúde; 2015.

33. Dewey KG. Is breastfeeding protective against child obesity? J Hum Lact. 2003;19(1):9-18.

34. World Health Organization. Long-term effects of breastfeeding: A systematic review. Geneva: WHO; 2013.

35. Scholtens S, Middelbeek L, Rutz SI, Buijs G, Bemelmans WJ. Differences in school environment, school policy and actions regarding overweight prevention between Dutch schools: A nationwide survey. Bmc Public Health. 2010;10:42.

36. Leary SD, Lawlor DA, Smith GD, Brion MJ, Ness AR. Behavioural early-life exposures and body composition at age 15 years. Nutr Diabetes. 2015;5(2):150-7.

37. Alexy L, Libuda G, Mersmann S, Kersting M. Convenience foods in children's diet and association with dietary quality and body weight status. Eur J Clin Nutr. 2011;65(2):160-6.

38. Sun C, Foskey RJ, Allen KJ, Dharmage SC, Koplin JJ, Ponsonby AL, et al. The impact of timing of introduction of solids on infant body mass index. J Pediatr. 2016;179:104-10. 